\title{
THE EFFECT OF MARKET STRATEgY ON MARKETING PERFORMANCE OF SMALlHOLdER RUBbER FARMERS IN Central Kuantan District, Kuantan Singingi REGENCY
}

\author{
Elizabet Sona Br Tambunan*, Shorea Khaswarina, Yeni Kusumawaty \\ Faculty of Agriculture, Riau University, Indonesia \\ *corresponding author: elizabethsona17@gmail.com
}

\begin{abstract}
This study aims to analyze the effect of market strategy on marketing performance in smallholder rubber in Kuantan Tengah District, Kuntang Singingi Regency, Riau. These market strategies include marketshaping, customer engagement, and technology leadership strategies. The population in this study found 225 people from 1 Gapoktan and 9 farmer groups in Kuantan Tengah District. The research sample was 15\% of the population, namely 34 people selected by the random sampling method. Data analysis used descriptive analysis and multiple linear regression models. The analysis results show that the respondent's level of achievement reaches $80,82 \%$ for market strategy and $74,22 \%$ for marketing performance, both of which are in the excellent level category. The value of sig.t for $\mathrm{X} 1$ is 0.861 , the value of sig.t for $\mathrm{X} 2$ is 0,342 , the value of sig.t for X3 is 0,585 is greater than the significance level $(\alpha)$, then the formation of market strategy, customer involvement, and technology leadership partially have no significant effect. Significant to marketing performance. The sig.F value of 0,728 is higher than the significance level $(\alpha)$, so the formation of market strategy, customer involvement, and technology leadership simultaneously do not significantly affect marketing performance.
\end{abstract}

Keywords: Customer Engagement, Market Formation, Market Performance, Technology Leadership

http://dx.doi.org/10.21776/ub.agrise.2022.022.1.4

Received 20 September 2021

Accepted 25 January 2022

Available online 31 January 2022

\section{INTRODUCTION}

Rubber plantations in Riau Province are spread in almost every district/city. Kuantan Singingi Regency is one of the largest rubber production centers in Riau Province, with the highest land area and rubber production. Kuantan Singingi Regency is an area with a rubber area of 137,722 Ha with an immature rubber plantation area (TBM) of 32,704 $\mathrm{Ha}$, an area of producing rubber plantations (TM) $80,709 \mathrm{Ha}$, and a rubber plantation with mature plants (TT) 24,309 Ha. Rubber production in Kuantan Singingi Regency is 84,859 tons with average productivity of $1,051 \mathrm{Kg} / \mathrm{Ha}$. The majority of rubber plantations in Kuantan Singingi Regency are community-owned plantations with 87,090 families of rubber farmers.

Central Kuantan District is one of the subdistricts in Kuantan Singingi Regency. Kuantan Tengah sub-district is one of the areas that produce bokar with the largest area of 13,670 hectares with an immature rubber plantation area (TBM) of 5,364 ha, mature plants (TM) 6,616 ha, and old plants (TT) 1,689 ha. Production of rubber plantations is $6,577 \mathrm{~kg}$, with a productivity of $994 \mathrm{~kg} / \mathrm{ha}$. Bokar produced by Kuantan Tengah District has low productivity compared to other sub-districts. This condition is caused by farming activities carried out by rubber farmers that are still not good, so rubber production is low. 
The production and productivity of rubber plantations in the Central Kuantan District are still relatively low. Low production and productivity are caused by the improper processing and maintenance of rubber. This condition makes the price of bokar received by farmers is still low. In addition, farmers also have to face price problems that tend to fluctuate due to various factors such as the influence of global rubber prices and long marketing channels. According to Saidali, et al (2019), marketing activities still experience many obstacles due to product innovation. Innovation in bokar farming activities is rubber treatment and processing techniques. This problem often arises and cannot be overcome because farmers cannot keep up with the knowledge and information that continues to grow. The combination of information technology and marketing can increase the development of bokar farming.

The low quality of farmers' bokar also impacts rubber marketing performance. In general, farmers sell rubber latex in processed rubber materials to customers. The processed rubber material is rubber latex mixed with coagulant and formed into lumps and then put together into a box shape. The processed rubber materials owned by farmers are then sold to customers/factories at relatively low prices. The price received by farmers is low because the bokar produced by farmers still has a low quality, not following the wishes of the customer/factory.

In this global era, performance is one of the primary keys to survival today. One of the factors often used to measure the impact of a strategy implemented by entrepreneurs is marketing performance. Good marketing performance is expressed in three main values: sales, customer, and productivity. Marketing performance is a benchmark of achievement obtained when conducting marketing activities. The company's effort to see the suitability of its strategy to deal with various environmental changes is to conduct a performance assessment. According to Gotteland, et al (2020), marketing proactivity is an aspect of corporate culture that emphasizes the importance of finding and satisfying current customer needs and future customers because corporate culture only affects the company's success

This study aims to determine how marketing strategies influence market formation, customer involvement, and technology leadership on the marketing performance of smallholder rubber in Central Kuantan District, Kuantan Singingi Regency. This marketing performance includes sales value, customer growth, and productivity growth. Knowing the right strategy is expected to improve marketing performance, which also impacts rubber marketing activities and the welfare of rubber farmers in Central Kuantan District, Kuantan Singingi Regency.

\section{RESEARCH METHODS}

\section{Research Locations and Respondent Samples}

This research was conducted in Central Kuantan District, Kuantan Singingi Regency. The research location was determined purposively with the consideration that Kuantan Tengah District is the largest rubber plantation area in Kuantan Singingi Regency. In addition, the District of Central Kuantan has farmer groups scattered throughout the village.

The method used in this study is a survey method through direct interviews and filling out questionnaires by respondents. According to Sugiyono (2018) the survey research method is a quantitative research method used to obtain data that occurred in the past or present, about beliefs, opinions, characteristics, behavior, variable relationships and to test several hypotheses about sociological and psychological variables from samples taken from certain populations, data collection techniques with observations (interviews or questionnaires) that are not in depth, and research results tend to be generalized. The population in this study are all rubber farmers who are members of farmer groups in Kuantan Tengah District. Central Kuantan sub-district has 9 farmer groups and 1 Gapoktan with 225 people.

According to Arikunto (2010) the sample is part of the population representing the entire population in a study. The sample in this study was $15 \%$ of the 225 farmer group members, namely 34 people who would represent the entire population of farmer group members in Kuantan Tengah District, Kuantan Singingi Regency. The sampling technique used is simple random sampling, meaning that the researcher provides equal opportunities for each member of the population (rubber farmers who are members of the farmer group) to be selected as a random sample without regard to the strata in the population itself.

\section{Data Analysis Techniques}

Data used in the study are primary data and secondary data. Primary data was obtained directly from the distribution of a list of questions or questionnaires to the selected respondents. Then 
interviews were conducted using the question and answer method directly with the respondents. Secondary data were obtained through books, literature, articles, journals, and sites on the internet related to the research conducted. Analysis of the data in this study uses descriptive analysis and multiple regression models to determine the regression equation of the effect of market formation, customer involvement, and technology leadership on marketing performance.

A classical assumption test is a statistical requirement that must be met in multiple linear regression analysis based on Ordinary Least Square (OLS). In principle, the linear regression model built should not deviate from the BLUE assumption (Best, Linear, Unbiased, and Estimator). Four classical assumption tests will be used in this study, including normality, heteroscedasticity, multicollinearity, and autocorrelation tests.

The multiple linear regression equation obtained using the formula:

$$
\mathrm{Y}=\mathrm{a}+\mathrm{b} 1 \mathrm{X} 1+\mathrm{b} 2 \mathrm{X} 2+\mathrm{b} 3 \mathrm{X} 3+€
$$

Information :

$\mathrm{Y}=$ Marketing performance

$\mathrm{a}=$ Intercept coefficient

b1 - b3 $=$ Coefficient of regression variable

$\mathrm{X} 1=$ Market Formation

$\mathrm{X} 2=$ Customer Engagement

X3 = Technology Leadership

$€=$ error term

The model analyzed is a test of the hypotheses carried out. It aims to see whether or not the effect of the selected variable is significant on the variables studied. Based on multiple linear regression analysis, the tests include simultaneous test (F-statistical test), partial test (statistical t-test), and the coefficient of determination R2

\section{RESULTS AND DISCUSSION}

\section{Descriptive Analysis}

Table 1. Respondents' level of achievement on market strategy

\begin{tabular}{|c|c|c|c|c|}
\hline No & Dimensions & $\begin{array}{l}\text { Total } \\
\text { Score }\end{array}$ & $\begin{array}{c}\% \\
\text { Score }\end{array}$ & Category \\
\hline 1 & $\begin{array}{l}\text { Market } \\
\text { formation } \\
\text { Customer }\end{array}$ & 876 & 85.88 & $\begin{array}{l}\text { Very } \\
\text { Good }\end{array}$ \\
\hline 2 & $\begin{array}{l}\text { Engagement } \\
\text { Technology }\end{array}$ & 685 & 67.16 & $\begin{array}{l}\text { Good } \\
\text { Very }\end{array}$ \\
\hline 3 & Leadership & 608 & 89.41 & Good \\
\hline & Total & 2169 & 80.82 & Good \\
\hline
\end{tabular}

Agricultural Socio-Economics Journal
Based on the results of data analysis, farmers have a positive response to the bokar market strategy, which includes market formation strategies, customer involvement, and technology leadership. The level of achievement of respondents reached $80.82 \%$, with a good rating category. Thus it can be said that the market strategy based on the result data is good. According to Brege \& Kindström (2019), a proactive market strategy is futureoriented, taking the initiative and driving change. The positive response stated that the market strategy applied in farming activities supported farmers' bokar marketing activities.

Table 2. Respondents' level of achievement on market performance

\begin{tabular}{|c|c|c|c|c|}
\hline No & Dimensions & $\begin{array}{l}\text { Total } \\
\text { Score }\end{array}$ & $\begin{array}{c}\% \\
\text { Score }\end{array}$ & Category \\
\hline 1 & $\begin{array}{l}\text { Sales Value } \\
\text { Customer }\end{array}$ & 252 & 74.12 & Good \\
\hline 2 & $\begin{array}{l}\text { Growth } \\
\text { Productivity }\end{array}$ & 226 & 66.47 & $\begin{array}{l}\text { Good } \\
\text { Very }\end{array}$ \\
\hline \multirow[t]{2}{*}{3} & Growth & 279 & 82.06 & Good \\
\hline & Total & 757 & 74.22 & Good \\
\hline
\end{tabular}

Source: Processed from primary data, 2021

Based on the results of data analysis, farmers have a positive response to the marketing performance of bokar, which includes sales value, customer growth, and productivity growth. The level of achievement of respondents reached $74.22 \%$, with a good rating category. According to Nemkova (2017), Marketing performance usually fluctuates because market changes cannot be ascertained. Uncertainty is defined as the inability to accurately predict the outcome of a decision due to insufficient information. The positive response stated that farmers facing the uncertainty of market changes were good for improving their marketing performance.

\section{Multiple Linear Regression Analysis}

\section{Test F - Statistics}

The F-test is a test simultaneously the significance of the effect of changes in the independent variable on the dependent variable. The test criteria are if sig. F 0.05 , then $\mathrm{H} 0$ is rejected, and $\mathrm{H} 1$ is accepted, and if sig. $\mathrm{F}>0.05$, then $\mathrm{H} 0$ is accepted, and $\mathrm{H} 1$ is rejected. If $\mathrm{HO}$ is accepted, it means that $\mathrm{X} 1, \mathrm{X} 2, \mathrm{X} 3$ simultaneously have no significant effect on $\mathrm{Y}$. If $\mathrm{H} 1$ is accepted, it means that $\mathrm{X} 1, \mathrm{X} 2, \mathrm{X} 3$ simultaneously have a significant effect on Y. From the SPSS results, the sig value is obtained. $\mathrm{F}$ is 0.728 , and this value is more than 0.05 , so it can be stated that $\mathrm{H} 1$ is rejected. Thus, the strategy of market formation, customer involvement, and technology leadership simultaneously have no significant effect on marketing performance. 


\section{Statistic $\mathrm{t}$ test}

The t-test is a partial test of the effect of the independent variable on the dependent variable, which is used to determine whether the independent variable partially has a significant effect on the dependent variable. The significance level $(\alpha)$ used in social science is 5\% (Supriana, 2013). Testing criteria is if sig. $\mathrm{t} 0.05$, then $\mathrm{H} 0$ is rejected and $\mathrm{H} 1$ is accepted and if sig. $\mathrm{t}>0.05$ then $\mathrm{H} 0$ is accepted and $\mathrm{H} 1$ is rejected. If $\mathrm{H} 0$ is accepted, it means that $\mathrm{X} 1$, $\mathrm{X} 2, \mathrm{X} 3$ partially have no significant effect on $\mathrm{Y}$. If $\mathrm{H} 1$ is accepted, $\mathrm{X} 1, \mathrm{X} 2, \mathrm{X} 3$ partially significantly affect Y. From the SPSS results, the sig.t value for $\mathrm{X} 1$ is 0.861 , the sig.t value is for $\mathrm{X} 20.342$, the sig.t value for X3 0.585 is greater than the significance level $(\alpha)$, so it can be stated that $\mathrm{H} 1$ is rejected. Based on the results of the data analysis, it can be stated that the market formation strategy, customer involvement, and technology leadership partially have no significant effect on marketing performance.

\section{Coefficient of Determination (R2)}

This coefficient shows the percentage of variation of all dependent variables that changes in the explanatory variables can explain. The value of the coefficient of determination (R2) ranges from 0 $<\mathrm{R} 2<1$, with the test criteria being that the higher R2 (closer to 1) indicates the model formed can explain the diversity of the dependent variable and vice versa. From the SPSS results, the coefficient of determination (R2) is 0.042 , where the value is greater than 0 and less than 1 . This means that the contribution of market formation, customer involvement, and marketing performance is $4.2 \%$, while $95.8 \%$ is determined by other factors not included in this study.

\section{Classical Assumption Test}

\section{a. Normality test}

The normality test in this study used the Kolmogorov-Smirnov statistical test. The research hypothesis is the Asymp value. Sig. (2-tailed) 0.05, the data is typically distributed. Meanwhile, if the value of Asymp. Sig. (2 - tailed) 0.05 the data is not normally distributed. Based on the results of data analysis using SPSS, the Asymp value was obtained. Sig. (2-tailed) is 0.788 . it can be concluded that the research data is usually distributed.

\section{b. Multicollinearity Test}

To detect the existence of multicollinearity by looking at the hypothesis if the Tolerance value < 0.10 or VIF $>10$ then multicollinearity occurs while if the Tolerance value $>0.10$ or VIF $<10$ then there is no multicollinearity. Based on the results of data processing using SPSS, the tolerance value is obtained and the VIF is as follows:
Table 3 Value of tolerance value and VIF variable Independent

\begin{tabular}{lcc}
\hline \multicolumn{1}{c}{ Variabel } & $\begin{array}{c}\text { Tolerance } \\
\text { Value }\end{array}$ & VIF \\
\hline Market formation & 0.898 & 1.114 \\
Customer Engagement & 0.978 & 1.022 \\
$\begin{array}{l}\text { Technology } \\
\text { Leadership }\end{array}$ & 0.895 & 1.117 \\
Source: Processed from primary data, 2021 &
\end{tabular}

Based on the information in the table, it can be seen that the tolerance value for all independent variables is more significant than 0.10 , and the VIF value for all variables is less than 10 , which means that there is no multicollinearity.

\section{c. Heteroscedasticity Test}

The heteroscedasticity test in this study used the glacier test. By using the basis of decision making as follows: If the Sig value of the independent variable $<0.05$, then heteroscedasticity occurs, whereas if the Sig value of the independent variable> 0.05 , then there is no heteroscedasticity. The significant value of the independent variable can be seen in the following table:

Table 4. The significance value of the independent Variable

\begin{tabular}{lc}
\hline \multicolumn{1}{c}{ Variable } & \multicolumn{1}{c}{$\begin{array}{c}\text { Significance of the } \\
\text { independent variable }\end{array}$} \\
\hline $\begin{array}{l}\text { Market formation } \\
\text { Customer }\end{array}$ & 0.413 \\
$\begin{array}{l}\text { Engagement } \\
\text { Technology }\end{array}$ & 0.359 \\
Leadership & 0.919 \\
Source: Processed from primary data, 2021
\end{tabular}

Based on the information in the table, it can be seen that all significant values of the independent variables are more than 0.05 , which means that there are no symptoms of heteroscedasticity.

\section{The Effect of Market Formation Strategy on Marketing Performance}

After the statistical $t$ test using SPSS, the significance value of the market formation strategy variable was 0.861 . The significance value is greater than the significance level of 0.05 . Thus, it can be concluded that the market formation strategy has no partial effect on marketing performance. According to Misra (2019), marketing in the business-tobusiness market (farmer group institutions) presents its own challenges for farmers. Farmers are trying to get the rubber factory to buy rubber at a higher price. Efforts made by farmers include finding out price information, making sales targets for bokar, conducting a price agreement process, processing bokar with gum vinegar according to the provisions, 
and seeking technological knowledge in the rubber business.

Some of the efforts made by these farmers have not been able to affect the level of rubber marketing performance. This is because the formation of a good market must involve a direct assessment of the factory as an actor in the marketing activities of bokar. According to Kindström (2017) market formation emphasizes the market as an element of an ongoing process, to be influenced and shaped by the actors involved (farmers and bokar factories) through their activities, and through coordinated activities of many actors (in this case farmer group institutions).

\section{The Effect of Customer Engagement Strategy on Marketing Performance}

The data processing results that tested the statistical $t$ value using SPSS found that the significance value of the customer engagement strategy variable was 0.342 . The significance value is greater than the significance level of 0.05 . Thus it can be concluded that the customer engagement strategy has no partial effect on marketing performance. Customer involvement is the main way for farmers to find market information regarding customer needs (Kumar \& Pansari, 2016).

Market information can be obtained by building relationships with customers. However, building relationships between farmers and customers (factories) does not directly improve rubber marketing performance. Farmers need to strengthen their customer management to ensure customer satisfaction, not just transactional contacts or relationship maintenance that enables farmers to achieve superior marketing performance (Pansari \& Kumar, 2017).

\section{The Effect of Technology Leadership Strategy on Marketing Performance}

The statistical t-test with SPSS obtained a significance value of the technology leadership strategy variable of 0.585 . The significance value is greater than the significance level of 0.05 . Thus it can be concluded that the technology leadership strategy has no partial effect on marketing performance. The ability of farmers to continue to innovate, find new ways/methods in the rubber business, use the internet to find out information on rubber prices, and take advantage of guidance/extension from the relevant agencies was not able to directly affect the marketing performance of farmers' bokar.

The ability of farmers to continuously innovate plays an essential role in developing solutions for customer needs. According to Herhaussen (2016) farmers can gain significant marketing performance benefits by balancing the exploration and exploitation aspects of the factory's decision to buy farmers' bokar, namely by increasing additional innovations in rubber farming. Farmers need to pay attention to customer (factory) needs, leading to strengthened innovation performance.

\section{The Effect of Market Strategy on Marketing Performance}

Based on the results of the statistical $F$ test data using SPSS, it was found that the significant $F$ value of 0.728 was greater than the significance level of 0.05 . The market strategy does not have a significant effect on marketing performance. The simultaneous market formation, customer engagement, and technology leadership have no significant effect on marketing performance. According to Nemkova (2017), market performance is characterized in terms of market share (such as market share growth) and sales indicators (such as sales volume, sales growth) of farmers' bokars. Marketing performance is volatile so farmers cannot ensure market changes.

Gotteland (2020) states that marketing proactivity emphasizes the importance of finding and satisfying the needs of current customers and the future. The success of marketing proactivity will affect the success of farmers' bokar farming if it can stimulate appropriate behavior to improve marketing performance. Thus a proactive market strategy will affect marketing performance if farmers also pay attention to customer ratings.

\section{CONCLUSION RECOMMENDATION}

Based on the descriptive analysis, the market strategy has a respondent's level of achievement reaching $80.82 \%$ with a good rating category. Thus it can be said that the market strategy based on the result data is good. Farmers have a positive response to marketing performance, with the achievement level of respondents reaching $74.22 \%$ in the excellent category.

The value of sig.t for $\mathrm{X} 1$ is 0.861 , the value of sig.t for $\mathrm{X} 2$ is 0.342 , the value of sig.t for $\mathrm{X} 3$ is 0.585 is greater than the significance level $(\alpha)$, then the formation of market strategy, customer involvement, and technology leadership partially have no significant effect. Significant to marketing performance.

The sig.F value of 0.728 is higher than the significance level $(\alpha)$, so the formation of market strategy, customer involvement, and technology leadership simultaneously do not significantly affect marketing performance.

A proactive market strategy cannot directly affect marketing performance. A good market must involve a direct assessment of the factory as an actor in bokar marketing activities. Farmers need to strengthen their customer management to ensure customer satisfaction, not just transactional contacts or relationship maintenance that supports farmers in 
achieving superior marketing performance. Farmers can improve marketing performance significantly by increasing additional innovations in rubber farming and paying attention to customer needs (rubber factory) which will lead to beneficial development performance.

Based on the research results, farmers need to pay attention that in their business, farmers are not proactive in marketing. Farmers must pay more attention to the needs of the factory (customers) in order to achieve superior marketing performance.

\section{REFERENCES}

Arikunto, S. 2010. Research Procedures A Practical Approach. Jakarta: Rineka Cipta.

Herhausen, D. (2016). Unfolding the ambidextrous effects of proactive and responsive market orientation. Journal of Business Research, 69(7), 2585-2593.

Kumar, V., \& Pansari, A. (2016). Competitive Advantage through Engagement. Journal of Marketing Research, Vol. 53, No. 4, pp.497514.

Pansari, A., \& Kumar, V. (2017). Customer Engagement: The Construct, Antecedents, and Consequences. Journal of the Academy of Marketing Science, Vol.45, No. 3, pp. 294- 311.

Nemkova, E. (2017). The impact of agility on the market performance of born-global firms: An exploratory study of the "Tech City" innovation cluster. Journal of Business Research, 80, 257265.

Kindström, D., Ottosson, M., \& Carlborg, P. (2018). Unraveling Firm-Level Activities for Shaping Markets Industrial Marketing Management, Vol. 68 (January), pp. 36-45.
Sugiyono. 2018. Quantitative, Qualitative, and R\&D Research Methods. Bandung: Alphabeta.

Saidali, J., Rahich, H., Tabaa, Y., \& Medouri, A. (2019). The combination between Big Data and Marketing Strategies to gain valuable Business Insights for better Production Success. Procedia Manufacturing, 32, 1017-1023.

Brege, H., \& Kindström, D. (2019). Exploring proactive market strategies. Industrial Marketing Management.

Mishra, S., Ewing, M. T., \& Pitt, L. F. (2019). The effects of an articulated customer value proposition (CVP) on promotional expense, brand investment and firm performance in $\mathrm{B} 2 \mathrm{~B}$ markets: A text based analysis. Industrial Marketing Management.

Riau Province Plantation Office (2019). Riau Province Plantation Statistics.

Ministry of Agriculture. (2020). Rubber Outlook 2020. Jakarta: Center for Agricultural Data and Information Systems -Secretariat General Ministry of Agriculture.

Central Bureau of Statistics (BPS). "Riau Province in Numbers". BPS catalog 1102002.14 accessed from http://www.bps.go.id/, accessed on 23 January 2021 at 18:17 WIB.

Gotteland, D., Shock, J., \& Sarin, S. (2020). Strategic orientations, marketing proactivity and firm market performance. Industrial Marketing Management. 